Csernicskó, István and Fenyvesi, Anna. "Sociolinguistic and Contact-induced Variation in Hungarian Language Use in Subcarpathia, Ukraine." AHEA: E-journal of the American Hungarian Educators Association, Volume 5 (2012): http://ahea.net/e-journal/volume-5-2012

\title{
Sociolinguistic and Contact-induced Variation in Hungarian Language Use in Subcarpathia, Ukraine ${ }^{1}$
}

István Csernicskó, II. Rákóczi Ferenc Subcarpathian Hungarian College, and Anna Fenyvesi, University of Szeged

Abstract: In addition to showing regional and social variation, the language use of the minority Hungarians of Subcarpathia, Ukraine, also presents a reflection of the region's complex linguistic history and its effects from contact with Russian and Ukrainian. On the basis of quantitative empirical findings, this study shows Subcarpathian Hungarians to be a sociolinguistically stratified group of speakers whose Hungarian language use varies in a systematic manner according to sex, age, level of education, and place of residence. The paper also outlines some of the main differences in the language use of Hungarians in Subcarpathia and Hungary which are manifested in statistically significant ways.

Keywords: language contact, sociolinguistic variation, Subcarpathia Hungarian, pluricentric language

Biographies: István Csernicskó was born in Chop, the westernmost town of the Soviet Union, in 1973. He received his university degree as teacher of the Hungarian language and literature at the Užgorod State University in independent Ukraine, and his PhD at Eötvös Loránd University in Budapest. He teaches at the II. Rákóczi Ferenc Subcarpathian Hungarian College, of which he is also vice rector.

Anna Fenyvesi is Associate Professor of English linguistics at the University of Szeged, Hungary. She received her PhD from the University of Pittsburgh. She is co-author of Hungarian (Descriptive Grammar series, Routledge, 1998) and editor of Hungarian Language Contact Outside Hungary (Benjamins, 2005).

\section{Introduction}

Following World War I, millions of ethnic Hungarians found themselves outside the political border of Hungary became citizens of other countries, namely Yugoslavia, Romania, the Soviet Union, Czechoslovakia, and Austria. Even though in the past nine decades many have chosen to re-emigrate to Hungary, communities numbering hundreds of thousands - or, in the case of Romania, millions - of Hungarians have remained in these countries and have been living in bilingual or multilingual settings ever since. Their language use and the growing sociolinguistic and linguistic effects of bilingualism were never studied empirically, or even merely systematically until the fall of communism. Under the four decades of communism after World War II, both in Hungary and in countries neighboring it the study or sometimes even the mention of Hungarian minorities was taboo, so that linguistic research was not made possible until after 1989. In the years since the collapse of the communist regime, sociolinguistic and linguistic

1 The present paper is a substantially revised and updated version of Csernicskó and Fenyvesi (2000). Thanks are due to Anikó Beregszászi, who, together with István Csernicskó, carried out most of the research reported on in this paper. 
Csernicskó, István and Fenyvesi, Anna. "Sociolinguistic and Contact-induced Variation in Hungarian Language Use in Subcarpathia, Ukraine.” AHEA: E-journal of the American Hungarian Educators Association, Volume 5 (2012): http://ahea.net/e-journal/volume-5-2012

information about Hungarians outside Hungary has become increasingly more available (see Bárdi et al. 2000, Beregszászi 1995/1996, Beregszászi and Csernicskó 2009, Botlik 2008, Csernicskó and Fenyvesi 2000, Csernicskó and Ferenc 2010, Csernicskó and Orosz 1999, Daftary and Gál 2000, Dickinson 2010, Fenyvesi 1995, several chapters in Fenyvesi 2005, Kocsis and Kocsis-Hodosi 1998, Kontra 1995a, 2001, 2003, Langman 2002, Langman and Lanstyák 2000, Lanstyák and Szabómihály 1996 and 2009, Péntek 2009, Sándor 2000, several chapters in Vančo ed. 2011, Zel'ová 1992 etc.).

In the present paper we discuss findings of a survey of Hungarian language use in Subcarpathia, Ukraine, which was part of the large scale research project "The Sociolinguistics of Hungarian Outside Hungary" (SHOH) describing the sociolinguistics of Hungarian language use in countries neighboring Hungary (for details on the project, see Kontra 2005). We discuss empirical, quantitative data that demonstrates differences in language use between the Hungarian varieties spoken in Hungary and in Subcarpathia, which point to a case of dialect divergence (Auer and Hiskens 1996: 15). Our most important findings are that the Hungarian community in Subcarpathia is not homogeneous in its language use and that the linguistic effects of bilingualism are not uniform across the members of this community.

Subcarpathia is the southwesternmost tip of Ukraine, situated between the divide of the Carpathian mountains and the national borders of Poland, Slovakia, Hungary, and Romania. ${ }^{2}$ It has traditionally been a multilingual and multiethnic region where Hungarians, Ukrainians, Russians, Ruthenians, Romanians, and Gypsies have lived together for centuries. The region formed an integral part of Hungary until 1920 when, under the Treaty of Trianon, it first became part of Czechoslovakia, and subsequently, during World War II was readjoined with Hungary. After the war it became part of the Ukrainian Soviet Socialist Republic, until, finally in 1991, it became part of independent Ukraine. Today Subcarpathia is one of Ukraine's 25 counties with a territory of 12,800 square kilometers, approximately the size of Connecticut (Magocsi 1996: 525). According to the figures of the latest, 2001, census, 156 thousand people, or $0.32 \%$ of the total population of Ukraine and $12.1 \%$ of the population of Subcarpathia, are of Hungarian ethnicity, while $12.6 \%$ claim to have Hungarian as their first language (Iltio 2003). Nearly all of Ukraine's ethnic Hungarian population live in Subcarpathia, the vast majority of them, 89\%, in the administrative districts around the four bigger towns — Užgorod/Ungvár, Mukačevo/Munkács, Berehove/Beregszász, and Vinogradiv/Nagyszőlős — stretching along the Hungarian-Ukrainian border (Shamshur and Izhevskaya 1993: 166, Magocsi 1996: 526). (Throughout this paper names of Subcarpathian towns and villages are given first transliterated, in their official Ukrainian versions, and, second in their traditional Hungarian forms.)

\section{The Study}

The range and depth of the existing linguistic descriptions of Hungarian language use in Subcarpathia is rather uneven. Relatively ample information is available about the traditional dialects of the region (e.g. Horváth 1976, Lizanec ${ }^{3} 1992$ and 1996, etc.), and some descriptive

\footnotetext{
${ }^{2}$ The region is also sometimes called Transcarpathia. Of its two names, 'Transcarpathia' ('the region beyond the Carpathians') reflects a Ukrainian perspective, whereas 'Subcarpathia' ('the region at the foothills of the Carpathians') a Hungarian one.

${ }^{3} \mathrm{P}$. N. Lizanec uses various Latin transliterations of his own name in different publications. We use the spelling of his name as it appears in each given publication.
} 
Csernicskó, István and Fenyvesi, Anna. "Sociolinguistic and Contact-induced Variation in Hungarian Language Use in Subcarpathia, Ukraine.” AHEA: E-journal of the American Hungarian Educators Association, Volume 5 (2012): http://ahea.net/e-journal/volume-5-2012

work has been done on various professional and social registers (for instance, Györke 1991). The has sociolinguistic and contact linguistic work done by Csernicskó and his co-authors to describe differences in Hungarian language use between Hungary and Subcarpathia and between various social groups within Subcarpathia has brought the bilingualism and language use of this sizeable European minority to the focus of attention in the international literature only in the past decade or so. Before the turn of the 21st century, for example, no mention was even made of the bilingualism of Subcarpathia's minority Hungarians in comprehensive reference books on European language contact situations such as Goebl et al. (1997). (For a discussion of the reasons for the absence of such work before, see Csernicskó 1997a.)

In the present paper we discuss a number of differences that we have found exist in the language use of Hungarians in Subcarpathia as compared with those in Hungary on the basis of an empirical survey conducted among Hungarians in Subcarpathia. We identify patterns in their language use and thereby demonstrate that social stratification exists in the Hungarian language use within this region. The work presented in this paper is part of a larger research project, The Sociolinguistics of Hungarian Outside Hungary, describing both the sociolinguistic situation of minority Hungarians in countries neighboring Hungary - specifically, Slovakia, Ukraine, Romania, Serbia, Slovenia, and Austria - in general and the stratification in language use among Hungarians in these countries (Kontra 2005). As part of The Sociolinguistics of Hungarian Outside Hungary project, the same questionnaire was administered to Hungarians in the six countries neighboring Hungary in order to allow for a cross-regional comparison of the Hungarian language use by minority Hungarians in these countries. The questionnaire method of data collection was chosen because it provided an equal amount of comparable data from the various groups of Hungarians. In order to make a comparison possible between the minority Hungarian groups and Hungarians in Hungary, the same questionnaire was also administered to a sample of 107 monolingual Hungarians from Hungary living in three villages, Ikrény, Veresegyház, and Szatymaz. ${ }^{4}$ The data from the survey was computerized with the help of the MEDIT coding program and statistically analyzed with the statistical software MINISTAT (Vargha 1996 and 1997).

Our survey was carried out in Subcarpathia in 1996 on a sample of 144 adult minority Hungarians stratified for age, education and settlement type. Data was collected (concerning language use and linguistic attitudes) on 324 sociolinguistic variables and on 60 linguistic variables. The subjects, slightly fewer men than women (71 and 73 subjects, respectively), were chosen to represent three age groups (ages 18-27, 32-52, and 60-81, with 48 subjects, or 33.3\% of the total, in each group), two different levels of education (elementary school educated vs. college educated, that is, with 8 vs. over 14 years of schooling (for a discussion of the reason for including only these two levels of education, see below), and with 76 subjects or $52.8 \%$ in the former group and 68 subjects or $47.2 \%$ in the latter), and four settlement types (towns vs. villages each with a majority vs. minority of Hungarian residents). ${ }^{5}$ The four settlement types

\footnotetext{
${ }^{4}$ We want to thank leader of the research project Miklós Kontra for making his data on the monolingual Hungarian control group available to us.

${ }^{5}$ The definition of places with a "minority population of Hungarians" used in the larger research project was towns or villages with a less than $30 \%$ minority population of Hungarians. However, for Subcarpathia, this cut-off point had to be raised to $45 \%$ in the case of villages, because in the four administrative districts along the Hungarian-Ukrainian border we only found villages either
} 
Csernicskó, István and Fenyvesi, Anna. "Sociolinguistic and Contact-induced Variation in Hungarian Language Use in Subcarpathia, Ukraine.” AHEA: E-journal of the American Hungarian Educators Association, Volume 5 (2012): http://ahea.net/e-journal/volume-5-2012

were represented by the Hungarian-majority town of Berehove/Beregszász (37 subjects, or $25.7 \%$ ), the Hungarian-minority town of Užgorod/Ungvár (36 subjects, or 25\%), the Hungarianmajority village of Esen'/Eszeny (36 subjects, or 25\%), and the Hungarian-minority villages of Rakošino/Beregrákos and Kholmok/Kincseshomok (35 subjects, or $24.3 \%$ ). ${ }^{6}$ (We had to collect data in two places for the last settlement type, since in these villages where Hungarians form a minority within the population of the village, we were not able to find enough subjects in only one place.)

Linguistic and sociolinguistic data were collected from the subjects in meetings where the field worker met with the subjects individually and asked them to fill out a questionnaire. We used the 'friend of a friend method' (Milroy 1980) to select the subjects that would fit our predetermined social categories. In every case the field worker was a member of the community under investigation, thus satisfying the requirement proposed by Poplack (1993: 260) that in investigations of bilingual communities data be collected by individuals who are members of the given community and are considered as such by the other members, and whose linguistic repertoire contains the linguistic features under investigation.

In the questionnaire, questions about sociolinguistic information were asked concerning the social and linguistic background of the subjects, their use of languages spoken by them in the various domains, and their attitudes to the three languages of the community, Hungarian, Russian, and Ukrainian. Linguistic questions targeted the linguistic features of the Hungarian used in Subcarpathia. The part of the questionnaire eliciting linguistic information contained a total of 69 questions requiring answers in one of 5 different task types covering 60 linguistic variables. The five tasks were the following:

- 1. Grammaticality judgments, sentence selection. The subject had to decide which one of two provided sentences s/he considered more acceptable;

- 2. Grammaticality judgments, sentence correction. The subject had to decide whether s/he regarded a sentence as acceptable or not, and if not, provide a correction of it;

- 3. Fill in the blanks, lexical. The subject had to fill one of two appropriate words or phrases provided into a sentence with a blank;

- 4. Fill in the blanks, inflectional. The subject had to use one of two choices of case endings provided for a given lexical item to fit into a sentence;

- 5. Fill in the blanks, profession name. The subject had to use a profession name whose meaning would fit a given sentence.

with a proportion of Hungarian population that we considered too small for our purposes, or with a minority population that amounted to more than $30 \%$ of the total.

${ }^{6}$ Because census data concerning minorities in the various settlements in the former Soviet Union is only partially available to the general public, we were not able to find information on what proportion of Hungarians in Subcarpathia live in each of our four settlement types in order to stratify our sample by settlement type accordingly. Therefore, we used an approximately equal number of subjects from each of the four settlement types. We were, however, able to find 1989 census data on what the proportion of Hungarians is in individual places: in nine of the ten Subcarpathian towns ethnic Hungarians constituted a minority, and only in one, Berehove/Beregszász a majority; in eight towns - in Užgorod/Ungvár among them - the proportion of Hungarian residents was under 30\% (cf. Csernicskó 1997b). 
Csernicskó, István and Fenyvesi, Anna. "Sociolinguistic and Contact-induced Variation in Hungarian Language Use in Subcarpathia, Ukraine.” AHEA: E-journal of the American Hungarian Educators Association, Volume 5 (2012): http://ahea.net/e-journal/volume-5-2012

The 60 linguistic variables targeted in the survey are of three kinds - we follow Lanstyák and Szabómihály (1996), a study on Hungarian as spoken in Slovakia, in classifying the linguistic variables as belonging to one of the three groups. First, we refer as Universal (U) variables ('egyetemes változó' in Hungarian; a term coined by Hungarian sociolinguists which is completely unrelated to that of language universal in Greenberg's sense) to the four linguistic features that are believed to occur in the entire Hungarian speech community, in both Hungary and outside Hungary. These, typically, have a variant that is accepted as the Standard Hungarian variant, and one that is considered nonstandard. (The use of imperative/subjunctive forms of $-t$ final verbs such as lát 'see' instead of their indicative forms as in nem lássuk a tévét 'we can't see the television' under the phenomenon commonly known as suksükölés in Hungarian is such a universal feature.) Second are those variables that, again, occur both inside and outside Hungary but whose nonstandard variants are phenomena that have parallels in Indo-European, and especially Slavic languages and, therefore, may be more frequent in the Hungarian used in areas where it is in contact with these languages, like in Subcarpathia. Because they occur universally in the Hungarian speech community but their use is reinforced in situations of more intense language contact such as that in Subcarpathia, following other Hungarian sociolinguists, we call these Universal Contact (UC) variables, of which eight are discussed in our paper - these variables occur inside Hungary as a result of the overall influence of Indo-European languages. (One such feature is the use of singular forms for paired body parts in Hungarian - as in fáj $a$ szemem 'my eyes hurt', kicsi a lábamra az új cipõ 'the new shoes are too small for my feet' - the equivalents of which are typically in the plural in Indo-European languages.) And, finally, the third kind of variables are the forms that are not present as variables inside Hungary but occur as such in Subcarpathia, and one variant of which is the Standard Hungarian realization (the only form that exists in Hungary), while the other is a form which is most likely the result of borrowing from Ukrainian and/or Russian and would constitute a nonstandard form in Hungary - we discuss four such variables and use the label Contact $(\mathrm{C})$ variables for them. (One such feature, for example, is the use of the verb becsönget meaning literally 'ring in' and used only with the meaning 'ring the bell' in Hungary but meaning 'make a phone call to' in Subcarpathia due to the influence of the Russian verb pozvonit' 'ring', meaning both 'ring the bell' and 'make a phone call to'.

The basic premise of the whole of The Sociolinguistics of Hungarian Outside Hungary project has been that there are differences between the Hungarian language use of monolingual Hungarians in Hungary and that of Hungarians living in bilingual environments outside Hungary. The three hypotheses concerning the linguistic variables that were formulated for the project are the following:

- Hypothesis A. There is a quantifiable difference in the acceptance of nonstandard forms in the two regions due to the fact that, as discussed above, the nonstandard variants of most of the variables are either contact features, or can be expected to become more frequent in a situation of language contact. More specifically, we expect to find a higher rate of acceptance of the nonstandard variants in Subcarpathia than in Hungary;

- Hypothesis B. Subjects from Hungary and subjects outside Hungary judge the nonstandard variants of the three kinds of variables (U, UC, and C) differently — for instance, it might be the case that monolingual Hungarians reject nonstandard variants that are purely contact features to a greater extent than do Hungarians outside Hungary; 
Csernicskó, István and Fenyvesi, Anna. "Sociolinguistic and Contact-induced Variation in Hungarian Language Use in Subcarpathia, Ukraine.” AHEA: E-journal of the American Hungarian Educators Association, Volume 5 (2012): http://ahea.net/e-journal/volume-5-2012

- Hypothesis $C$. Across both areas, a statistically significant correlation exists between a number of social variables (such as age, sex, education, and settlement type) and the acceptance of the variants of the linguistic variables.

Our hypotheses have indeed been proven correct, as has been discussed in detail in studies describing the linguistic situation in the Hungarian communities of the various countries under investigation. For information on this in English, see Lanstyák and Szabómihály (2005) regarding Slovakia, Csernicskó (2005) regarding Ukraine, Benõ and Szilágyi N. (2005) on Romania, and Göncz and Vörös (2005) on Serbia and Slovenia.

In the rest of this paper we present our findings on 16 linguistic variables morphological, morphosyntactic, and lexical - illustrating all three kinds of linguistic features (i.e. Universal, Universal Contact, and Contact variables) and discussed below under the headings of seven linguistic phenomena: the indicative and imperative/subjunctive/subjunctive of $t$-final verbs, compounds, synthetic versus analytical constructions, singular and plural of nouns, agreement of nouns, feminine forms of profession nouns, and calques.

The indicative and imperative/subjunctive/subjunctive of $t$-final verbs

In Standard Hungarian, the present tense definite conjugation ${ }^{7}$ indicative paradigm of verbs ending in - $t$ (the forms látja and tanítja of verbs such as lát 'see', tanít 'teach' etc.) is distinct from and has no homonymous forms with the definite conjugation forms in the imperative/subjunctive of these verbs (such as lássa and tanitsa, respectively). However, in some of the traditional regional dialects, those spoken in Subcarpathia among them (Lizanyec and Horváth 1981: 17), and in nonstandard Hungarian, the imperative/subjunctive forms of $t$-final verbs are used in the indicative as well, resulting in a morphological merger of the two paradigms in the definite conjugation (nonstandard examples are nem lássa, mit csinál? 'can't you see what you are doing?' or Lakatos tanár úr idén nem tanítsa az osztályunkat 'Mr. Lakatos won't be teaching our class this year' vs. nem látja and nem tanítja in the standard). A universal Hungarian feature (and so, in our terms, a Universal variable), such usage is very heavily stigmatized as uneducated in Hungarian (Kontra 1995b, and Váradi and Kontra 1995) and most strongly discouraged by prescriptive literature on usage both in Hungary (Grétsy and Kovalovszky 1983: 618) and in Subcarpathia (see, for instance, Balogh 1991, Horváth 1991, and Kótyuk 1995: 46-47).

In our survey we used two items to elicit the forms in question: one for verbs ending in a vowel and - $t$, válogat 'choose' in sentence 1 below, and one for verbs ending in an obstruent and $t$, halasz $t$ 'postpone' in sentence 2 . Subjects had to fill in a verb ending that they considered appropriate in the following two sentences: ${ }^{8}$

${ }^{7}$ In Hungarian, all finite verbs are inflected for either the indefinite or the definite conjugations: the verb is indefinite if it is intransitive, or if it is transitive and governs an indefinite object (typically, an object noun phrase with an indefinite article); and the verb is definite if it is transitive and governs a definite object, usually a proper noun or a noun phrase with a definite article. (For more details on the definite vs. indefinite conjugations, see Kenesei, Vago and Fenyvesi 1998:321-327.)

${ }^{8}$ Throughout this paper, hyphens indicate morpheme boundaries in example sentences. Orthographically, no hyphens would be used in any of the sentences. In the morpheme-by- 
Csernicskó, István and Fenyvesi, Anna. "Sociolinguistic and Contact-induced Variation in Hungarian Language Use in Subcarpathia, Ukraine.” AHEA: E-journal of the American Hungarian Educators Association, Volume 5 (2012): http://ahea.net/e-journal/volume-5-2012

Ha Péter rossz-ul váloga__ meg a barát-ai-t,
if Peter bad-ESS choose_ PFX the friend-POSS.3SG-ACC discomfited
jár.'
go.INDEF.3SG
'If Peter chooses his friends badly, he'll soon be discomfited.'
Mi-nek ez a halogatás? Nem szeret-em, ha valaki
what.DAT this the delay not like.DEF.1SG if somebody
el-hala_
PFX-postpone_a the decision-PL-ACC
'Why this delay? I don't like it when somebody postpones making decisions.'

In the two sentences, the verbs with the standard indicative endings are válogatja (choose.DEF.3SG) and elhalasztja (PFX.postpone.DEF.3SG), while the nonstandard options are válogassa (choose.IMP.DEF.3SG) and elhalassza (PFX.postpone.IMP.DEF.3SG), respectively, with, in the latter example, the imperative/subjunctive forms of $t$-final verbs the stem-final $t$ undergoing complete assimilation.

The results for the two sentences are shown in Table 1. The figures show that bilingual Hungarians in Subcarpathia choose the standard forms as grammatical less frequently than monolingual Hungarians in Hungary. Similar results were found by Lanstyák and Szabómihály when they tested the same phenomenon among Hungarian high school students in Slovakia and in Hungary: standard forms were chosen less frequently in the former group than in the latter,

morpheme glosses of the Hungarian sentences we use the following abbreviations (see examples of the use of these morphemes in bold in brackets):

$1 \mathrm{SG}$ - first person singular (látom 'I see it'), 2SG - second person singular (látod 'you see it'), 3SG - third person singular (látja 's/he sees it'), 1PL - first person plural (látjuk 'we see it'), 3PL - third person plural (látják 'they see it'), ABL - ablative case (a háztól 'from the house'), ACC accusative case ( $a$ házat 'the house [when used as an object]'), ADE - adessive case (a háznál 'at the house'), ADER - suffix deriving an adjective (házi feladat 'homework'), APRT - active (present) participle (állva 'standing'), CAU - causative derivational suffix (csináltat 'have sth made'), DAT - dative case (Jánosnak 'to John'), DEF - definite conjugation (nézi 's/he watches it'), EMPH - emphasis marker (már), ESS - essive case (magyarul 'in Hungarian'), IMP imperative (állj fel! 'stand up!'), INDEF - indefinite conjugation (látok 'I see'), INE - inessive case (a házban 'in the house'), INS - instrumental case (a késsel 'with the knife'), MOE - modalessive case (gyorsan 'quickly'), NDER - suffix deriving a noun (utazás 'travel'), PAST - past tense (állt 's/he stood'), PFX - verbal prefix (feláll 'stand up'), PL - plural (házak 'houses'), POSS - possessive personal ending (háza 'his/her house'), POT - potential suffix (állhat 'may stand'), Q - question particle (áll-e 'whether s/he/it stands'), REF - reflexive derivational suffix (szépitkezik 'beautify oneself'), SUB - sublative case (a házra 'onto the house'), SUP superessive case (a házon 'on the house'), TRA - translative case (házzá '[turn] into a house'), VDER - suffix deriving a verb (jelez 'signal').

${ }^{9}$ Throughout this paper, morpheme-by-morpheme glosses are provided for example sentences in Hungarian. 
Csernicskó, István and Fenyvesi, Anna. "Sociolinguistic and Contact-induced Variation in Hungarian Language Use in Subcarpathia, Ukraine.” AHEA: E-journal of the American Hungarian Educators Association, Volume 5 (2012): http://ahea.net/e-journal/volume-5-2012

both in the type of task where students had to supply a form missing from a sentence and in the one where they had to choose the form they considered right out of two alternative forms (1996: 116, and 1997: 31-33).

Table 1. The choice of standard versus nonstandard indicative forms of $t$-final verbs among speakers in Subcarpathia and in Hungary.

\begin{tabular}{||c|c|c||}
\hline & $\begin{array}{c}\text { Subcarpathia } \\
(\mathrm{N}=144)\end{array}$ & $\begin{array}{c}\text { Hungary } \\
(\mathrm{N}=107)\end{array}$ \\
\hline Sentence 1: standard (válogatja) & $78.3 \%$ & $96.0 \%$ \\
nonstandard (válogassa) & $21.7 \%$ & $4.0 \%$ \\
\hline nontence 2: standard (elhalasztja) & $47.9 \%$ & $91.5 \%$ \\
\hline
\end{tabular}

Sentence 1: The Chi-square test shows the difference to be significant

$$
\left(\chi^{2}=15.12372 ; p=.0001\right)
$$

Sentence 2: The Chi-square test shows the difference to be significant

$$
\left(\chi^{2}=33.93573 ; \mathrm{p}=.000001\right)
$$

Another difference also clearly stands out if the proportions of standard vs. nonstandard answers for the two sentences calling for válogatja/válogassa 's/he chooses' and elhalasztja/elhalassza 's/he postpones', respectively, are compared: in the case of the verb ending in an obstruent $+t$ (sentence 2, elhalasztja/elhalassza), nonstandard answers were given in a much greater number of times, over half of the time, in Subcarpathia than for the verb ending in vowel $+t$ (sentence 1 , válogatja/válogassa). A similar tendency, although of much smaller magnitude, exists in the answers of the Hungarian control group. This finding demonstrates that the stigmatization of the merger of the indicative and imperative/subjunctive forms is greater in the case of verbs ending in vowel $+t$ than in the case of those ending in obstruent $+t$, which is in accordance with the findings of the Hungarian National Sociolinguistic Survey (see Váradi and Kontra 1995).

As a result of the heavy stigmatization of the nonstandard usage of imperative/subjunctive forms, such as lássa in place of the indicative form, such as látja in the indicative meaning 's/he sees it', a universal tendency for hypercorrection exists among speakers of Hungarian in the entire Hungarian speech community, resulting in many speakers using indicative forms where imperative/subjunctive forms would be required (such as saying nem 
Csernicskó, István and Fenyvesi, Anna. "Sociolinguistic and Contact-induced Variation in Hungarian Language Use in Subcarpathia, Ukraine." AHEA: E-journal of the American Hungarian Educators Association, Volume 5 (2012): http://ahea.net/e-journal/volume-5-2012

akarom, hogy látja instead of the standard nem akarom, hogy lássa for 'I don't want him/her to see it') stemming from their insecurity about which form is 'correct' and overcompensating in such a way that in the end they choose the 'wrong one'. This hypercorrection, then, is another Universal variable, that is, a feature that occurs in the entire Hungarian speech community, both in and outside Hungary. In order to see to what extent such hypercorrection exists also in Subcarpathia, subjects were asked in sentence 3, below, to fill in an ending that they considered appropriate and to supply the appropriate form of the verb megválaszt 'to elect' in $4:{ }^{10}$

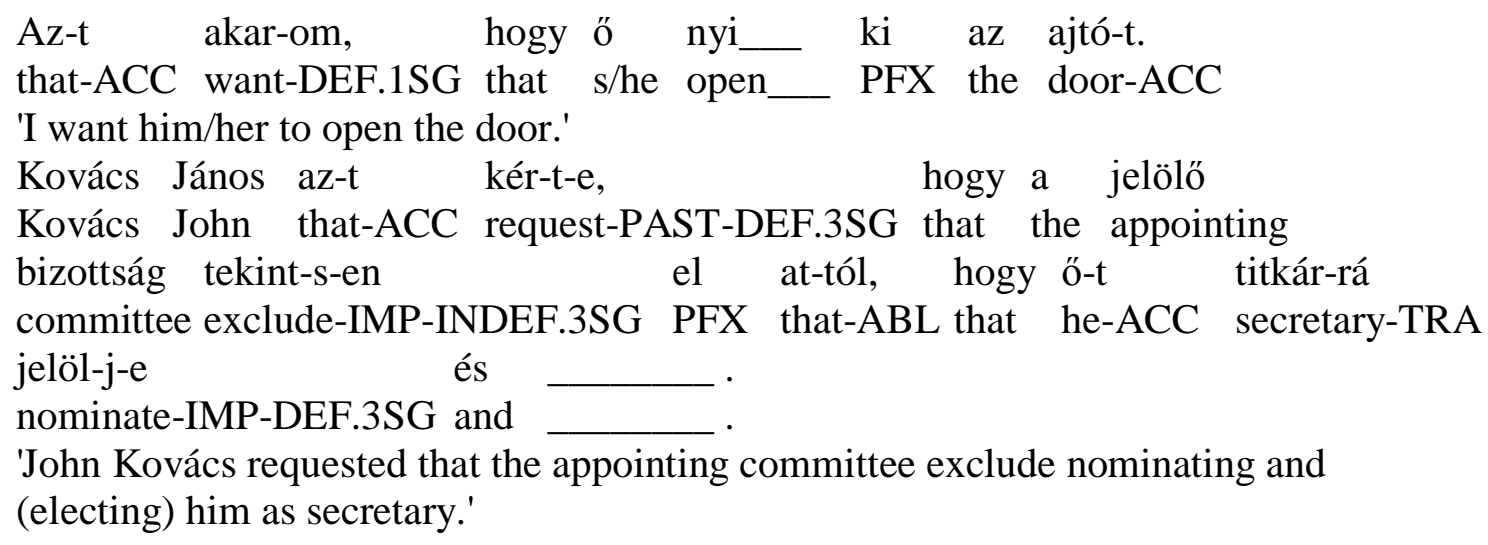

In both sentences a grammatically imperative/subjunctive verb form (used in the subjunctive function is required. The standard verb choice is nyissa (open.IMP.DEF.3SG) and megválassza (elect.IMP.DEF.3SG), whereas the hypercorrect answer is the indicative form nyitja (open.DEF.3SG) and megválasztja (elect.DEF.3SG), respectively.

As the results in Table 2 indicate, for sentence 3 the proportion of respondents choosing the hypercorrect form (that is, the one which is nonstandard in the given context but which the linguistically insecure speakers use in the belief that they are being 'correct') in Subcarpathia was virtually identical with that of respondents in Hungary. Answers for the obstruent $+t$ verb nyitja (sentence 4) were, however, somewhat different in the two places: hypercorrect forms were given more frequently in Subcarpathia than in Hungary. This demonstrates that obstruent $+t$ verbs behave differently than vowel $t$ verbs also in respect to hypercorrection - as has also been evidenced by Lanstyák and Szabómihály's findings among Hungarian high school students in Slovakia (1997: 34-35).

\footnotetext{
${ }^{10}$ Whenever the task involved required subjects to fill in a complete word, this word is indicated by a blank in the Hungarian sentences and the line containing the morpheme-by-morpheme glosses, and by the appropriate word supplied in brackets in the English translation, as in sentence 4 , for instance.
} 
Csernicskó, István and Fenyvesi, Anna. "Sociolinguistic and Contact-induced Variation in Hungarian Language Use in Subcarpathia, Ukraine." AHEA: E-journal of the American Hungarian Educators Association, Volume 5 (2012): http://ahea.net/e-journal/volume-5-2012

Table 2. The choice of standard versus hypercorrect imperative forms of $t$-final verbs among speakers in Subcarpathia and in Hungary.

\begin{tabular}{||c|c|c||}
\hline & $\begin{array}{c}\text { Subcarpathia } \\
(\mathrm{N}=144)\end{array}$ & $\begin{array}{c}\text { Hungary } \\
(\mathrm{N}=107)\end{array}$ \\
\hline Sentence 3: standard (nyissa) & $96.5 \%$ & $96.3 \%$ \\
hypercorrect (nyitja) & $3.5 \%$ & $3.7 \%$ \\
Sentence 4: standard (megválassza) & $86.3 \%$ & $94.4 \%$ \\
hypercorrect (megválasztja) & $13.7 \%$ & $5.6 \%$ \\
\hline
\end{tabular}

Sentence 3: The Chi-square test shows the difference to not be significant

$$
\left(\chi^{2}=.013 ; \mathrm{p}=.911\right)
$$

Sentence 4: The Chi-square test shows the difference to be significant

$$
\left(\chi^{2}=3.83306 ; \mathrm{p}=.050\right)
$$

\section{Compounds}

In Standard Hungarian compounds are formed through the concatenation of both derived and underived stems: vízágyú 'water cannon' is formed by combining underived stems, that is, two simple nouns together, víz 'water' and ágyú 'cannon', while vízisí 'water ski (n.)' by combining the denominal adjective vízi and the underived stem sí 'ski'. In the case of roots like viz that can appear in the nonhead position in both derived and underived forms, the root of a specific compound cannot vary freely between the derived and underived forms in different compounds, that is, for instance, vízágyú cannot be replaced by *víziágyú, or vízisí by *vízsí. Because in Slavic languages such as Russian and Ukrainian, compounding of two nouns is extremely rare - these languages employ phrases involving a relational adjective and a head noun instead of compounding, e.g. Russian vodnye lyži (vod-n-ye lyž-i, water-ADER-PL ski-PL) 'water ski' - contact varieties of Hungarian in contact with Slavic languages often employ compounds with denominal adjective nonheads instead of the standard compounds whose nonhead is underived. The items that were included to test such compounds are the phrases bankszámla (bank+számla) 'bank account' and légtér (lég+tér) 'air space', where the forms banki számla (bank-i számla 'bank-ADER account') and légitér (lég-i tér 'air-ADER space') are nonstandard in Hungarian usage. A Universal Contact variable, this kind of compounds was targeted with sentences 5 and 6: in 5 subjects were asked to judge the sentence (containing the nonstandard variant) and correct it if they thought it would be better in a different way, while in 
Csernicskó, István and Fenyvesi, Anna. "Sociolinguistic and Contact-induced Variation in Hungarian Language Use in Subcarpathia, Ukraine.” AHEA: E-journal of the American Hungarian Educators Association, Volume 5 (2012): http://ahea.net/e-journal/volume-5-2012

6 they had to fill in what they considered to be the correct form, i.e. standard légterét or nonstandard légi terét, both meaning 'air space (ACC)':

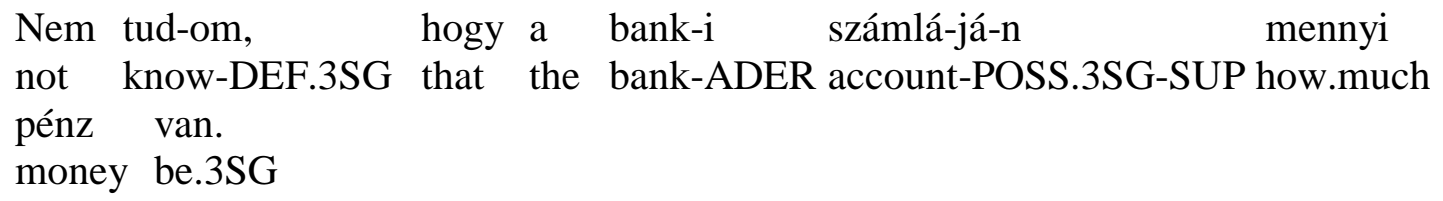
A repülőgép-ek meg-sért-ett-ék
Svájc
the air.plane-PL PFX-violate-PAST-INDEF.3PL Switzerland
'The airplanes violated Switzerland's (air space).'

Table 3 shows the results for this variable: Hungarians in Subcarpathia accept the nonstandard variant to a greater extent than Hungarians in Hungary, although the difference is not statistically significant in the case of sentence 5. The differences in the acceptance rate of the standard forms of the two items in both places as well as the relatively low percentage rate of standard answers in the case of sentence 5 stand out. Even though this can perhaps be due to the fact that compounds with a denominal adjectival premodifier (that is, the kind of vízisí 'water ski') are numerous in Hungarian and their frequency might increase subjects' willingness to accept a nonstandard compound of this kind, we believe that the reason, at least partly, lies in the task involved in sentence 5, whose effect we discuss in the next subsection.

Table 3. The choice of a standard versus nonstandard compound among speakers in Subcarpathia and in Hungary.

\begin{tabular}{|c|c|c||}
\hline & $\begin{array}{c}\text { Subcarpathia } \\
(\mathrm{N}=144)\end{array}$ & $\begin{array}{c}\text { Hungary } \\
(\mathrm{N}=107)\end{array}$ \\
\hline Sentence 5: standard (bankszámláján) & $25.9 \%$ & $35.5 \%$ \\
nonstandard (banki számláján) & $74.1 \%$ & $64.5 \%$ \\
\hline Sentence 6: standard (légterét) & $49.3 \%$ & $90.7 \%$ \\
nonstandard (légi terét) & $50.7 \%$ & $9.3 \%$ \\
\hline
\end{tabular}

Sentence 5: The Chi-square test shows the difference to not be significant

$$
\left(\chi^{2}=3.23455 ; \mathrm{p}=.072\right)
$$

Sentence 6: The Chi-square test shows the difference to be significant

$$
\left(\chi^{2}=47.41931 ; \mathrm{p}=.001\right)
$$


Csernicskó, István and Fenyvesi, Anna. "Sociolinguistic and Contact-induced Variation in Hungarian Language Use in Subcarpathia, Ukraine." AHEA: E-journal of the American Hungarian Educators Association, Volume 5 (2012): http://ahea.net/e-journal/volume-5-2012

Synthetic vs. analytical constructions

There are a number of constructions where Standard Hungarian uses highly synthetic forms (where meanings are expressed by morphemes attached to a stem, such as hegedül 'play the violin') where the Slavic languages which Hungarian is in contact with in Subcarpathia or Slovakia employ analytical forms (of the kind such as hegedûn játszik 'play the violin' - lit. 'play on the violin' - where meaning is expressed in independent words making up a phrase). In at least one variety of Hungarian which is in contact with a Slavic language, notably Hungarian spoken in Slovakia, analytical forms replacing the standard Hungarian synthetic forms have been identified and attributed to the effect of language contact with Slovak (Lanstyák and Szabómihály 1997: 78). These constructions constitute Universal Contact variables, existing universally in the Hungarian speech community, but as the result of language contact.

In our survey we included three variables where Standard Hungarian variants are synthetic constructions, while nonstandard variants are parallel analytical constructions whose use is either purely the result of the contact of Hungarian with Russian and Ukrainian, or intensified by such contact. Two variables are of a kind where Standard Hungarian expresses an action with a synthetic verb form incorporating its complement by morphological means. As a result of language contact, however, such verbs are often replaced by verbs with their complements expressed as noun phrases in varieties of Hungarian which are in contact with Slavic languages. Thus, in both Slovakia and Subcarpathia the latter kind of constructions coexist with the former. One variable we used is Standard Hungarian buszozás (busz-oz-ás, busVDER-NDER) 'traveling by bus', a nominal form of a derived denominal verb, whose nonstandard variant of the same meaning is an analytical verb phrase utazás busszal (utaz-ás busz-szal, travel-NDER bus-INS). The other variable is Standard Hungarian szépitkezik (szépítkezik, beautify-REF) 'to beautify oneself' — a verb which is made reflexive through the derivational suffix -kezik - and whose nonstandard analytical variant is szépíti magát (szépít-i magá-t, beautify-DEF.3SG self-ACC). For the former, subjects were asked to choose, from two sentences (standard 7a or nonstandard 7b), the one which they considered better, whereas for the latter they had to fill in what they regarded as the correct form (i.e. standard szépitkezik or nonstandard szépíti magát) for sentence 8:

(7)(a) Un-om már ez-t a sok busz-oz-ás-t. be.tired-DEF.1SG EMPH this-ACC the much bus-VDER-NDER-ACC 'I'm very tired of all this traveling by bus.'

(7)(b) Un-om már ez-t a sok utazás-t busz-szal. be.tired-DEF.1SG EMPH this-ACC the much travel-ACC bus-INS 'I'm very tired of all this traveling by bus.'
A tükör elött hossz-an
the mirror in.front.of long-MOE

'She (beautified herself) in front of the mirror for a long time.'

The third variable, which we targeted with two different questions, is the Standard Hungarian inflectional suffix -hat/-het marking potential (having the ability, the opportunity, the permission, the possibility, or the right to act), whose nonstandard contact variant is the use of the auxiliary tud 'be able to', normally expressing either learned ability or potential due to 
Csernicskó, István and Fenyvesi, Anna. "Sociolinguistic and Contact-induced Variation in Hungarian Language Use in Subcarpathia, Ukraine." AHEA: E-journal of the American Hungarian Educators Association, Volume 5 (2012): http://ahea.net/e-journal/volume-5-2012

circumstances. This feature is not found in Hungarian as spoken in Hungary, and is therefore a Contact (rather than a Universal Contact) variable. Bartha (1993: 138) has found this feature in the speech of Hungarian Americans in Detroit, too, and considers it the most striking replacement of synthetic forms by analytical ones in contact varieties of Hungarian. The two cases for this variable were sentence 9 , where subjects had to judge the sentence (which contained the nonstandard variant) and, if they thought it needed correction, to correct it, and 10, where subjects were asked to choose the sentence which they considered to be the correct one (10a with the standard form, or $10 \mathrm{~b}$ with the nonstandard one):

$$
\begin{aligned}
& \text { Ha szellőztet-ni akar-ok, így kér-ek engedély-t: } \\
& \text { if air-INF want-INDEF.1SG this.way ask.for-INDEF.1SG permission-ACC } \\
& \text { ki tud-om nyit-ni az ablak-ot? } \\
& \text { PFX be.able-DEF.1SG open-INF the window-ACC } \\
& \text { 'If I want to air the room, I ask for permission this way: 'Can I open the window?" }
\end{aligned}
$$

(10)(a) Tanító néni, fáj a fej-em. Ki-me-het-ek? teacher aunt ache.INDEF.3SG the head-POSS.1SG PFX-go-POT-INDEF.1SG 'Miss, I have a headache. May I go out?'

(10)(b) Tanító néni, fáj a fej-em. Ki tud-ok teacher aunt ache.INDEF.3SG the head-POSS.1SG PFX be.able-INDEF.1SG men-ni? go-INF

'Miss, I have a headache. May I go out?'

The results for the four questions are given in Table 4. As the percentages show, of the four items, the proportion of standard answers was lower in Subcarpathia than in Hungary in the case of two (sentences 8 and 10), that is, in the case of these items, in line with our expectations, Hungarians in Subcarpathia favored analytical forms to a greater extent than Hungarians in Hungary did. 
Csernicskó, István and Fenyvesi, Anna. "Sociolinguistic and Contact-induced Variation in Hungarian Language Use in Subcarpathia, Ukraine." AHEA: E-journal of the American Hungarian Educators Association, Volume 5 (2012): http://ahea.net/e-journal/volume-5-2012

Table 4. The choice of standard synthetic versus nonstandard analytical forms among speakers in Subcarpathia and in Hungary.

\begin{tabular}{|c|c|c||}
\hline \hline & $\begin{array}{c}\text { Subcarpathia } \\
(\mathrm{N}=144)\end{array}$ & $\begin{array}{c}\text { Hungary } \\
(\mathrm{N}=107)\end{array}$ \\
\hline nonstandard (utazást busszal) & $37.8 \%$ & $53.4 \%$ \\
\hline Sentence 8: standard (szépítkezett) & $62.2 \%$ & $46.7 \%$ \\
nonstandard (szépítette magát) & $36.8 \%$ & $80.0 \%$ \\
\hline Sentence 9: standard (kinyithatom) & $83.2 \%$ & $81.3 \%$ \\
nonstandard (ki tudom nyitni) & $14.6 \%$ & $18.7 \%$ \\
\hline Sentence 10: standard (kimehetek) & $94.4 \%$ & $97.2 \%$ \\
nonstandard (ki tudok menni) & $5.6 \%$ & $2.8 \%$ \\
\hline \hline
\end{tabular}

Sentence 7: The Chi-square test shows the difference to be significant $\left(\chi^{2}=9.58621 ; \mathrm{p}=.002\right)$

Sentence 8: The Chi-square test shows the difference to be significant $\left(\chi^{2}=8.21083 ; \mathrm{p}=.004\right)$

Sentence 9: The Chi-square test shows the difference to not be significant $\left(\chi^{2}=.75811 ; \mathrm{p}=.384\right)$

Sentence 10: The Chi-square test shows the difference to not be significant $\left(\chi^{2}=1.109 ; \mathrm{p}=.292\right)$

We should also note that if we arrange by type of task the four items for synthetic vs. analytical constructions plus the item involving the underived vs. derived compound discussed in the previous subsection, as in Table 5, we find that questions where subjects were asked to do sentence correction, i.e. a task requiring relatively greater effort, in both Subcarpathia and Hungary more nonstandard variants were supplied than in the cases when subjects had to choose between two given alternatives in the sentence selection task and the lexical fill in the blanks 
Csernicskó, István and Fenyvesi, Anna. "Sociolinguistic and Contact-induced Variation in Hungarian Language Use in Subcarpathia, Ukraine.” AHEA: E-journal of the American Hungarian Educators Association, Volume 5 (2012): http://ahea.net/e-journal/volume-5-2012

task. This finding most likely indicates that the type of task bears an effect on the results for these questions.

Table 5. The effect of the task type on the results of items for compounds and synthetic vs. analytical constructions.

\begin{tabular}{|r|c|c||}
\hline & $\begin{array}{c}\text { Standard answers in } \\
\text { Subcarpathia }\end{array}$ & $\begin{array}{c}\text { Standard answers in } \\
\text { Hungary }\end{array}$ \\
\hline Task: Sentence correction - Sentence 5 & $25.9 \%$ & $35.5 \% \%$ \\
Sentence 6 & $62.2 \%$ & $53.3 \%$ \\
\hline Task: Sentence selection - Sentence 7 & $63.2 \%$ & $80.0 \%$ \\
Sentence 8 & $85.5 \%$ & $81.3 \%$ \\
\hline Task: Fill in the blank, lexical - Sentence 9 & $94.4 \%$ & $97.2 \%$ \\
Sentence 10 & $49.3 \%$ & $90.7 \%$ \\
\hline
\end{tabular}

The singular and plural of nouns

In a number of cases Standard Hungarian uses singular number marking in nouns where Indo-European languages typically have plural, such as paired body parts (such as ears, arms and legs, cf. leégett a karom 'my arms got sunburnt', lit. 'my arm burned down') and nouns denoting a large set of identical items (cf. megjelent a zöldségesnél a meggy és a málna 'sour cherries and raspberries appeared at the vegetable stand', lit. 'the sour cherry and the raspberry appeared at the vegetable stand'). In nonstandard Hungarian in Hungary plural marking sometimes occurs in such cases due to the overall influence of Indo-European languages on Hungarian. Furthermore, plural agreement has been shown to occur more pronouncedly in varieties of Hungarian in situations of bilingualism where Hungarian speakers are in close contact with at least one such Indo-European language, namely, Slovak (Lanstyák and Szabómihály 1996: 119 and 1997: 8084). Such cases of number marking are also Universal Contact variables, that is, linguistic features that occur in the entire Hungarian linguistic area but do so as a result of Hungarian's many centuries long contact with Indo-European languages in the Carpathian Basin.

We examined number marking in two phenomena, body parts occurring in pairs, and generic reference to a class of things, such as the examples with cherries and raspberries in the previous paragraph, for both of which Standard Hungarian employs singular. Body parts 
Csernicskó, István and Fenyvesi, Anna. "Sociolinguistic and Contact-induced Variation in Hungarian Language Use in Subcarpathia, Ukraine." AHEA: E-journal of the American Hungarian Educators Association, Volume 5 (2012): http://ahea.net/e-journal/volume-5-2012

occurring in pairs (e.g. eyes, ears, hands, arms, feet, legs, etc.) and pieces of clothing belonging to such body parts (e.g. trousers, shorts, shoes, etc.) are referred to in the singular and receive singular subject-verb agreement. In reference to a group of identical items, too, the singular is used in Standard Hungarian (cf. szép almát vettem 'I bought beautiful apples', lit. 'I bought a beautiful apple'), while in nonstandard usage, the plural is used in both of these cases. In sentence 11a subjects had to fill in missing endings for number marking on body parts and person/number marking on verbs agreeing with the body parts:

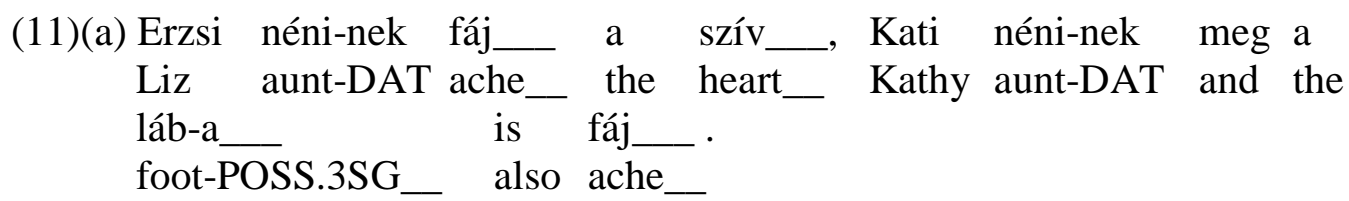

'Aunt Liz has a pain in her heart [lit. her heart aches] and Aunt Kathy has aching feet [lit. her feet ache].'

In Standard Hungarian the correct answers are as in $11 \mathrm{~b}$ and $11 \mathrm{c}$, whereas the nonstandard variant of the second phrase is as in 11d (as the first phrase involves the heart, a non-paired body part, it therefore does not have a nonstandard variant):

Standard:

(b) fáj ache.INDEF3SG the heart-POSS.3SG 'her heart aches'

(c) a láb-a is fáj the foot-POSS.3SG also ache.INDEF.3SG 'her feet ache, too'

(11)(d) Nonstandard: a láb-a-i fój-nak the foot-POSS.3SG-POSS.PL also ache-INDEF3PL 'her feet ache, too'

For the second variable, subjects had to choose which sentence they considered as more correct, sentence $12 \mathrm{a}$, the standard variant with singular number marking, or sentence $12 \mathrm{~b}$, the one with nonstandard plural marking:

(12)(a) Néz-d, milyen szép banán-t árul-nak az üzlet-ben! look-IMP.2SG what beautiful banana-ACC sell-INDEF.3PL the store-INE 'Look, what beautiful bananas are being sold in the store!'

(12)(b) Néz-d, milyen szép banán-ok-at árul-nak az üzlet-ben! look-IMP.2SG what beautiful banana-PL-ACC sell-INDEF.3PL the store-INE 'Look, what beautiful bananas are being sold in the store!'

Table 6 summarizes the results for these two variables: the proportion of standard answers is higher in Hungary for both. These results agree with similar findings that were reported about number marking in the speech of Hungarian high school students in Slovakia and Hungary (Lanstyák and Szabómihály 1996: 119, and 1997: 81). 
Csernicskó, István and Fenyvesi, Anna. "Sociolinguistic and Contact-induced Variation in Hungarian Language Use in Subcarpathia, Ukraine." AHEA: E-journal of the American Hungarian Educators Association, Volume 5 (2012): http://ahea.net/e-journal/volume-5-2012

Table 6. The choice of standard versus nonstandard number marking among speakers in Subcarpathia and in Hungary.

\begin{tabular}{|c|c|c||}
\hline \hline & $\begin{array}{c}\text { Subcarpathia } \\
(\mathrm{N}=144)\end{array}$ & $\begin{array}{c}\text { Hungary } \\
(\mathrm{N}=107)\end{array}$ \\
\hline $\begin{array}{c}\text { Sentence 11: standard (fáj a lába) } \\
\text { nonstandard (fájnak a lábai) }\end{array}$ & $32.2 \%$ & $94.9 \%$ \\
\hline Sentence 12: standard (banánt) \\
nonstandard (banánokat)
\end{tabular}

Sentence 11: The Chi-square test shows the difference to be significant

$$
\left(\chi^{2}=25.53270 ; \mathrm{p}=.001\right)
$$

Sentence 12: The Chi-square test shows the difference to be significant

$$
\left(\chi^{2}=19.55079 ; \mathrm{p}=.001\right)
$$

\section{Agreement features}

In a small number of cases, Standard Hungarian uses singular number agreement where most Indo-European languages (and, under their overall influence, nonstandard Hungarian usage in Hungary) employ the plural. We hypothesized that, just like in number marking, in these cases (which, again, constitute Universal Contact features that occur in the entire Hungarian language area as a result of the influence of languages Hungarian has been in contact with) the use of the nonstandard Slavic-like variants is more widespread in varieties of Hungarian in closer contact with Slavic languages. For instance, in cases where plural subjects are related to one thing of the same kind each (e.g. as in 'The boys sit on chairs', where for every boy there is one chair), the noun expressing the thing to which the subjects are related appears in the singular in Standard Hungarian. This phenomenon was tested in sentence 13, where subjects had to fill in either the standard autóban (autó-ban, car-INE) 'in the car', or the nonstandard autókban (autó-k-ban, carPL-INE) 'in cars', depending on which they thought fit the sentence better (both variants were given after the sentence):
$\mathrm{Az}$ autó-s
mozi-ban az utas-ok
movies-INE the passenger-PL

néz-het-ik a film-et.

watch-POT-DEF.3PL the movie-ACC

'In drive-in movies the passengers watch the movie sitting in their cars.'

In Standard Hungarian agreement is also singular on adjectival phrases when plural subjects or objects have adjectival complements governed by verbs (cf. a régi barátokat képviselõvé választották 'the old friends were elected representatives', lit. 'the old friends were elected representative'), while in such cases Slavic languages like Russian and Ukrainian (or 
Csernicskó, István and Fenyvesi, Anna. "Sociolinguistic and Contact-induced Variation in Hungarian Language Use in Subcarpathia, Ukraine.” AHEA: E-journal of the American Hungarian Educators Association, Volume 5 (2012): http://ahea.net/e-journal/volume-5-2012

other Indo-European languages like English) employ plural agreement (cf. the old friends were elected representatives). This phenomenon was included in two sentences, 14 (with a subject complement) and 15 (with an object complement): in 14 subjects had to select one of the two sentences, standard (a) or nonstandard (b), whichever they considered better, while in 15 they had to fill in one of the two supplied phrases in the sentence, standard komolynak (komoly-nak, serious-DAT) or nonstandard komolyaknak (komoly-ak-nak, serious-PL-DAT).

(14)(a) A mai gyerek-ek at-tól vál-nak önző-vé, hogy the today child-PL that-ABL become-INDEF.3PL selfish-TRA that minden-t meg-kap-nak. everything-ACC PFX-get-INDEF.3PL 'Modern children become selfish because they get everything [that they want].'

(14)(b) A mai gyerek-ek at-tól vál-nak önző-k-ké, hogy the today child-PL that-ABL become-INDEF.3PL selfish-PL-TRA that minden-t meg-kap-nak. everything-ACC PFX-get-INDEF.3PL 'Modern children become selfish because they get everything [that they want].'
A képviselö-k
az ok-ok-at tart-ott-ák. the representative-PL the reason-PL-ACC consider-PAST-DEF.3PL 'The representatives considered the reasons (serious).'

The proportions of standard singular agreement are higher in Hungary than in Subcarpathia in the case of all three sentences (see Table 7).

Table 7. The choice of standard versus nonstandard agreement marking among speakers in Subcarpathia and in Hungary.

\begin{tabular}{|c|c|c||}
\hline \hline nonstandard (autókban) & $\begin{array}{c}\text { Subcarpathia } \\
(\mathrm{N}=144)\end{array}$ & $\begin{array}{c}\text { Hungary } \\
(\mathrm{N}=107)\end{array}$ \\
\hline Sentence 13: standard (autóban) & $59.4 \%$ & $86.9 \%$ \\
\hline Sentence 14: standard (önzövé) & $40.6 \%$ & $13.1 \%$ \\
nonstandard (önzökké) & $40.3 \%$ & $70.1 \%$ \\
\hline Sentence 15: standard (komolynak) & $59.7 \%$ & $29.9 \%$ \\
nonstandard (komolyaknak) & $54.2 \%$ & $70.1 \%$ \\
\hline
\end{tabular}


Csernicskó, István and Fenyvesi, Anna. "Sociolinguistic and Contact-induced Variation in Hungarian Language Use in Subcarpathia, Ukraine." AHEA: E-journal of the American Hungarian Educators Association, Volume 5 (2012): http://ahea.net/e-journal/volume-5-2012

Sentence 13: The Chi-square test shows the difference to be significant

$$
\left(\chi^{2}=22.53166 ; \mathrm{p}=.001\right)
$$

Sentence 14: The Chi-square test shows the difference to be significant

$$
\left(\chi^{2}=21.90664 ; \mathrm{p}=.001\right)
$$

Sentence 15: The Chi-square test shows the difference to be significant

$$
\left(\chi^{2}=14.67554 ; \mathrm{p}=.001\right)
$$

\section{Feminine forms of profession nouns}

Hungarian does not mark grammatical gender anywhere in its grammatical system, and nouns denoting professions do not express gender through derivation as they do in Russian or Ukrainian (cf. Russian doktor '[male] doctor' vs. doktorša 'female doctor'). It is only rarely possible in Hungarian to indicate that a person in a profession is female: compounded forms involving a profession designation followed by the head nö 'woman' are used in the case of professions either typically (or sometimes exclusively) occupied by females (e.g. varrónö 'dressmaker', védönö 'district nurse', or apácafönöknö 'mother superior') or when the noncompounded form refers specifically to a male (cf. király 'king' vs. királynö 'queen', színész 'actor' vs. színésznö 'actress', or szakács 'chef, cook' vs. szakácsnő 'female cook'). (For more on this issue from the linguistic and gender related aspect, see also Vasvári 2011.) The number of compounded female profession nouns used on a regular basis is rather limited, Papp (1969) lists only slightly more than 60. In the case of the rest of all profession nouns, whenever it is clear from the context that the person referred to is a female, the noncompounded profession noun is used, and a compounded form is only used to make unambiguous reference to a female when no clues are available from the context. Varieties of Hungarian in contact with Slavic languages namely, with Slovak - have been previously shown to employ compounded feminine profession nouns even when not necessitated by the context, as in Anyám fodrásznak tanult, $\tilde{o}$ fodrász/fodrásznõ 'my mother trained to be a hairdresser, so she is a hairdresser/female hairdresser' (Lanstyák and Szabómihály 1996: 122-123).

In our survey we used three sentences to examine the use of such profession nouns. Sentences 16 and 17 were given as continuous text, while 18 was included under a separate item number, and subjects had to fill in one of two variants provided after each sentence, depending on which one they thought would fit the sentence better. The choices were standard tanár 'teacher' and nonstandard tanárnö 'female teacher' for 16, standard igazgató 'headmaster' and nonstandard igazgatónö 'headmistress' for 17, and standard fodrász 'hairdresser' and nonstandard fodrásznő 'female hairdresser' for 18.

$$
\begin{aligned}
& \text { Anyá-m egy középiskolá-ban tanít, ő tehát } \\
& \text { mother-POSS.1SG a high.school-INE teach.INDEF.3SG she so } \\
& \text { 'My mother teaches in a highschool, so she is (a teacher). } \\
& \text { Tavaly ki-nevez-t-ék az iskola él-é-re, most tehát } \\
& \text { last.year PFX-appoint-PAST-DEF.3PL the school top-POSS.3SG now so } \\
& \text { már } \\
& \text { already } \\
& \text { 'Last year she was appointed to lead the school, so now she is (a headmistress).' }
\end{aligned}
$$


Csernicskó, István and Fenyvesi, Anna. "Sociolinguistic and Contact-induced Variation in Hungarian Language Use in Subcarpathia, Ukraine.” AHEA: E-journal of the American Hungarian Educators Association, Volume 5 (2012): http://ahea.net/e-journal/volume-5-2012
Kovács Juli-t
már
régóta
ismer-em.
Mióta
Kovács Julie-ACC already for.long.time know-DEF.1SG since
ide-költöz-t-ünk, nál-a csinál-tat-om
here-move-PAST-INDEF.1PL ADE-3SG do-CAU-DEF.1SG
a frizurá-m-at, vagyis ö a
the hairdo-POSS.1SG-ACC thus she the

'I have known Julie Kovács for a long time. Ever since we moved here I have been having her do my hair, that is, she is (my hairdresser).'

As Table 8 demonstrates, in the case of all three items, the proportion of standard answers (tanár 'teacher' and fodrász 'hairdresser' etc.) was higher in Hungary than in Subcarpathia. The number of standard answers, however, is clearly lower in the case of sentence 16 than in the other two sentences for both groups of subjects. This is most likely due to the fact that the form tanárnö 'female teacher' is used as a form of address towards female teachers - it is, indeed, by far the most common address form for a teacher used universally by both students and their parents, and can be used by nonteaching school staff as well. Even though igazgatónö 'headmistress' can also be used as a form of address, it is much less common due to the fact that females occupy the post of headmasters traditionally much rarer than males. The form fodrásznö 'female hairdresser', however, cannot be used as a form of address. We are indebted for this explanation to Lanstyák and Szabómihály (1997: 73).

Table 8. The choice of standard versus nonstandard profession nouns among speakers in Subcarpathia and in Hungary.

\begin{tabular}{|c|c|c||}
\hline \hline & $\begin{array}{c}\text { Subcarpathia } \\
(\mathrm{N}=144)\end{array}$ & $\begin{array}{c}\text { Hungary } \\
(\mathrm{N}=107)\end{array}$ \\
\hline Sentence 16: standard (tanár) & $31.3 \%$ & $58.7 \%$ \\
nonstandard (tanárnó) & $68.8 \%$ & $41.3 \%$ \\
\hline Sentence 17: standard (igazgató) & $77.6 \%$ & $82.5 \%$ \\
nonstandard (igazgatónó) & $22.4 \%$ & $17.5 \%$ \\
\hline Sentence 18: standard (fodrászom) & $72.2 \%$ & $89.5 \%$ \\
nonstandard (fodrásznóm) & $27.3 \%$ & $10.5 \%$ \\
\hline
\end{tabular}


Csernicskó, István and Fenyvesi, Anna. "Sociolinguistic and Contact-induced Variation in Hungarian Language Use in Subcarpathia, Ukraine." AHEA: E-journal of the American Hungarian Educators Association, Volume 5 (2012): http://ahea.net/e-journal/volume-5-2012

Sentence 16: The Chi-square test shows the difference to be significant

$$
\left(\chi^{2}=19.15658 ; \mathrm{p}=.001\right)
$$

Sentence 17: The Chi-square test shows the difference to not be significant

$$
\left(\chi^{2}=.94080 ; \mathrm{p}=.332\right)
$$

Sentence 18: The Chi-square test shows the difference to be significant

$$
\left(\chi^{2}=10.61161 ; \mathrm{p}=.001\right)
$$

\section{Calques}

Hungarians in Subcarpathia frequently use calques, that is, mirror translations from Russian and Ukrainian in their Hungarian. We examined their acceptance of calqued forms in a test situation with two variables, kiirrat (ki-írat, out-write.CAU) 'subscribe', and becsenget (becsenget, in-ring) 'telephone', calqued on Russian vypisat' (vy-pisat', out-write) and pozvonit' (pozvonit', PFX-ring), respectively. The standard Hungarian forms for the two verbs are elofizet (elö-fizet, pre-pay) 'subscribe' and telefonál 'telephone'. Both calques are widely used in Subcarpathia but have been stigmatized by local prescriptivists (cf. Horváth 1991, Kótyuk 1995: 63-64). Both are forms that can clearly be considered contact features of Hungarian in Subcarpathia that do not exist in Hungary with the above meanings. The two verbs have different meanings in Standard Hungarian: kiirrat means 'get oneself certified as sick (by doctor)', while becsenget means 'ring doorbell'. The two calqued verbs were included in sentences 19 and 20, respectively, where subjects had to judge the two sentences and to correct them if they thought they needed to be corrected.

Péter er-re az év-re is ki-ír-at-t-a $\quad$ is
Peter this-SUB the year-SUB also out-write-CAU-PAST-DEF.3SG the Kárpáti
Igaz Szó-t.
Igaz Szó-ACC

'Peter subscribed to Kárpáti Igaz Szó for this year as well.'

$\begin{array}{ll}\text { Edit tegnap be-csenget-ett } & \text { a vasút-ra, hogy } \\ \text { Edith yesterday in-ring-PAST.INDEF.3SG the railway-SUB that } \\ \text { meg-kérdez-z-e, } & \text { késik-e }\end{array}$

PFX-ask-IMP-DEF.3SG be.late.INDEF.3SG-Q the train

'Yesterday Edith called the railway station to ask whether the train was late.'

The standard variant for the verbs in question is eloffizette 's/he subscribed' and telefonált 's/he telephoned'.

The results for the two sentences, 19 and 20, are summarized in Table 9. It is not surprising that Subcarpathian subjects had a high acceptance rate for the nonstandard calqued forms - after all, they have parallels in another language of this multilingual population. We find the relatively high acceptance rates of the nonstandard variants by subjects in Hungary rather unexpected, however. The reason for such relatively high acceptance can perhaps lie in a combination of three factors. First, calques may be less discernible to monolingual Hungarians than loanwords. Second, the use of calques is less stigmatized as foreign and therefore incorrect and undesirable by prescriptivist language cultivators in Hungary, who have been publicly expressing their anti-loanword views amidst an influx of loanwords in recent years. The third possible factor lies in the design of the survey: sentences 19 and 20 involved the sentence 
Csernicskó, István and Fenyvesi, Anna. "Sociolinguistic and Contact-induced Variation in Hungarian Language Use in Subcarpathia, Ukraine." AHEA: E-journal of the American Hungarian Educators Association, Volume 5 (2012): http://ahea.net/e-journal/volume-5-2012

correction task, which, as we have shown in connection with sentences 6 and 7 above, may have an effect on subjects' answers.

Table 9. The choice of standard vs. nonstandard calqued verbs among speakers in Subcarpathia and in Hungary.

\begin{tabular}{|c|c|c||}
\hline & $\begin{array}{c}\text { Subcarpathia } \\
(\mathrm{N}=144)\end{array}$ & $\begin{array}{c}\text { Hungary } \\
(\mathrm{N}=107)\end{array}$ \\
\hline Sentence 19: standard (elöfizette) & $17.4 \%$ & $66.0 \%$ \\
nonstandard calque (kiirratta) & $82.6 \%$ & $34.0 \%$ \\
\hline Sentence 20: standard (telefonált) & $29.2 \%$ & $56.7 \%$ \\
nonstandard calque (becsengetett) & $70.8 \%$ & $43.3 \%$ \\
\hline
\end{tabular}

Sentence 19: The Chi-square test shows the difference to be significant $\left(\chi^{2}=55.58110 ; \mathrm{p}=.001\right)$

Sentence 20: The Chi-square test shows the difference to be significant $\left(\chi^{2}=21.62264 ; \mathrm{p}=.001\right)$

We believe that the clearly high acceptance of the nonstandard calqued forms by the Subcarpathian subjects requires an explanation beyond the effect of the type of linguistic task that the forms were tested through, which, as we have seen, may foster an acceptance of nonstandard forms. These calques, together with a numerous others, such as (pénzt) cserél 'exchange (money)' and (vizsgát) lead 'pass (an exam) (in Standard Hungarian: [pénzt] vált and [vizsgát] letesz, respectively), constitute a part of what is best regarded as a Subcarpathian Standard Hungarian variety. As has been argued for by Beregszászi (1997) and Csernicskó (1997c), this variety displays the characteristics of a standard variety and should, therefore, be acknowledged as such, along with other regional standard varieties of Hungarian such as Slovakia Standard Hungarian and Transylvanian Standard Hungarian and included in dictionaries that play a significant role in codifying Standard Hungarian. Among the first results of the attempts to have Subcarpathian Standard Hungarian and the other regional standard varieties acknowledged has been the inclusion of words from these varieties in the 2nd, revised edition of the Concise Defining Dictionary of Hungarian (Pusztai ed. 2003) and a new defining dictionary of Hungarian published by Tinta Kiadó, Eöry (ed. 2007). Of the Subcarpathia Standard Hungarian variety the words csenget 'make a phone call' and (vizsgát) lead 'pass (an exam)' are two of the approximately three dozen words included in the former dictionary. Such inclusion of regional standard words in major dictionaries published in Hungary and the 
Csernicskó, István and Fenyvesi, Anna. "Sociolinguistic and Contact-induced Variation in Hungarian Language Use in Subcarpathia, Ukraine." AHEA: E-journal of the American Hungarian Educators Association, Volume 5 (2012): http://ahea.net/e-journal/volume-5-2012

acknowledgement of their source varieties that this entails reinforces the view proposed by Lanstyák (1995a, 1995b) and Lanstyák and Szabómihály (1997) and shared by us that Hungarian is a pluricentric language (that is, a language with more than one national variety and a different set of linguistic norms, like German, English, Spanish etc.) and should be regarded as such, with all the linguistic and sociolinguistic consequences that this means. (For more on pluricentric languages, see Clyne ed. 1992 and Clyne and Kipp, eds. 1999. For a discussion of how the idea of pluricentiricity of Hungarian was received by conservative linguists in Hungary, see Kontra 1997. For an online database of regional standard vocabulary of Hungarian used in countries neighboring Hungary, see http://ht.nytud.hu/htonline/htlista.php?action=firstpage)

\section{$\underline{\text { Social differences in language use }}$}

Next we want to discuss some characteristics of Hungarian language use in Subcarpathia which reflect social characteristics of speakers. In our study we used the following social variables: sex (2 groups), age ( 3 groups: young, middle aged, and elderly), education ( 2 groups: elementary school educated and college educated), and settlement type. For the latter variable we used 4 groups in Subcarpathia along the village vs. town, and minority vs. majority Hungarian population oppositions. For the Hungary control group we used one settlement type, villages, due to the monolingual Hungarian data available. For more details of the social variables and criteria, see above.

Sex showed a statistically significant correlation with linguistic variables in 3 cases (variables 14, 15, and 18) ${ }^{11}$ in Subcarpathia, and in 6 cases (variables 8-11, 14, and 15) in Hungary. In all cases, women had higher rates for standard variants than men, as has been the case in all sociolinguistic studies everywhere where gender has been found to be a significant factor of variation in the use of standard forms (Chambers 1995: 102-145).

In 3 cases each in the Subcarpathian sample and the sample from Hungary age was statistically significant. In each of the 3 linguistic variables in question, the subjects from Hungary who had the highest rate for standard forms were the oldest group, those over 60, and in 2 of these 3 cases the youngest group (18-27-year-olds) had the lowest rates for standard forms.

The results were more varied in the case of Subcarpathians. For variable 7 (synthetic structure buszozás vs. analytical utazás busszal 'traveling by bus'), at the $\mathrm{p}<.01$ level, the highest rate of standard answers was given by the youngest group, a lower rate by the middle aged group (32-52-year-olds), and the lowest by the oldest group. In the case of variable 13 (use of singular autóban vs. plural autókban 'in car/s'), at the $\mathrm{p}<.05$ level, however, the youngest group was the least standard, and the oldest the most standard. In the case of the third variable, sentence 19 (the use of kiirat with the specifically Subcarpathian Hungarian meaning of 'subscribe'), the highest rate of standard answers was supplied by the middle aged group, a lower rate by the youngest group, and the lowest by the oldest group, at the $\mathrm{p}<.05$ level for age.

Thus, we can see that the results are mixed for age as an independent variable. We believe that we do not have enough evidence to propose an explanation of this rather mixed picture. We can, however, safely conclude that our results demonstrate that the widely held but empirically hithertofore unsupported belief that the speech of the oldest generation is least

"For brevity's sake, in this section we refer to the linguistic variables discussed in section 5 by the numbers of the sentences they occur in - the reader should refer back to this section for linguistic details. 
Csernicskó, István and Fenyvesi, Anna. "Sociolinguistic and Contact-induced Variation in Hungarian Language Use in Subcarpathia, Ukraine." AHEA: E-journal of the American Hungarian Educators Association, Volume 5 (2012): http://ahea.net/e-journal/volume-5-2012

affected by the linguistic results of language contact while that of the youngest displays the most interference (cf. for instance Horváth 1998) cannot be maintained.

The results where the level of education is a statistically significant factor can only be taken with some caution due to the fact that the educational systems of Ukraine and Hungary have crucial differences. The main difference is that in Hungary elementary education has traditionally been 8 years followed by 4 years of secondary education, while Ukraine, similarly to the rest of the former Soviet Union, has had 10-year schools comprising in one and the same school type the 8 years of elementary and the two years of secondary education. (College education is similarly 4 or 5 years in both countries.) Because completion of secondary education would thus mean 12 years or education in Hungary and only 10 in Subcarpathia, we used only the two education levels that are more comparable to each other in the two countries, namely elementary vs. college education.

Level of education played a statistically significant role in the results for several linguistic variables in Subcarpathia, and for some in Hungary. In the case of all linguistic variables, in both places, college education correlated in a statistically significant way with standard forms.

Settlement type was included as a variable only in the case of the Subcarpathian sample, not in the Hungary sample. In treating settlement type in Subcarpathia we used two two-way distinctions: town (Užgorod/Ungvár and Berehove/Beregszász) vs. village (Esen'/Eszeny, Rakošino/Beregrákos and Kholmok/Kincseshomok), and Hungarian population in local majority (Berehove/Beregszász and Esen'/Eszeny) vs. local minority (Užgorod/Ungvár, Rakošino/Beregrákos and Kholmok/Kincseshomok). For more details about the settlements in question, see above.

The town vs. village distinction was statistically significant in the case of several linguistic variables. In the case of all of these linguistic variables, residence in a town correlated with standard answers.

The majority vs. minority status of Hungarians in a place showed statistical significance in the case of several variables again, and, not surprisingly, in all cases residence in a place with a Hungarian population in the majority correlated with standard answers.

\section{Discussion}

In 13 of the 16 variables that we examined, the rate of standard answers was higher in Hungary than in Subcarpathia, and only in 3 (variables 3, 7, and 9) was the reverse true. This confirms our Hypothesis A. It also supports the widely accepted view that the varieties of Hungarian used in minority settings are characterized more by the use of dialectal and regional features and are less standard than the Hungarian spoken in Hungary (cf. Deme 1970: 39, Lanstyák 1994: 64, Sándor 1995: 132-133, or, specifically on the Hungarian spoken in Subcarpathia, Horváth 1991, and Kótyuk 1995: 7). To date, this view has been supported empirically only in the case of the variety of Hungarian spoken in Slovakia (Szabómihály 1993, and Lanstyák and Szabómihály 1996 and 1997).

The three kinds of linguistic variables - the Universal, Universal Contact, and Contact variables - that we identified and used were judged differently, confirming our Hypothesis B. The three kinds of variables, then, cannot be treated uniformly in the future - after all, their acceptance by members of a speech community is not uniform either. Our expectation that the monolingual control group from Hungary would firmly reject and stigmatize nonstandard 
Csernicskó, István and Fenyvesi, Anna. "Sociolinguistic and Contact-induced Variation in Hungarian Language Use in Subcarpathia, Ukraine.” AHEA: E-journal of the American Hungarian Educators Association, Volume 5 (2012): http://ahea.net/e-journal/volume-5-2012

variants of Contact variables was not fulfilled (see our discussion of variables 18 and 19 in above).

As discussed above, we have identified statistically significant correlations between linguistic and social variables, thereby demonstrating that a social stratification exists in the use of Hungarian in Subcarpathia and confirming our Hypothesis C. Our results demonstrate that education and type of settlement are especially important social variables determining Hungarian language use in Subcarpathia, while sex and, surprisingly for us, age play a more minor role. An important finding for sociolinguistic research on monolingual Hungarians is that age plays a lesser role than sex and education in Hungary as well.

\section{Conclusions}

In this study we have demonstrated that statistically significant differences in Hungarian language use exist between monolingual speakers in Hungary and bilingual (or multilingual) speakers in Subcarpathia, thereby showing that the Hungarian community of Subcarpathia cannot be treated as sociolinguistically homogeneous and disproving traditional views to the contrary: whatever scarce literature on the bilingualism and Hungarian language use in Subcarpathia that has existed so far has regarded this Hungarian community as unified in its language use, giving rise to the false notion that bilingualism has the exact same type of effect on virtually every member of the community and uniformly to the exact same extent (see, for instance, Rot 1967 and Kótyuk 1995) (a similar phenomenon has been noted in connection with other bilingual communities by Fishman 1968: 29-30). Further research will, of course, be needed to describe Hungarian language use and bilingualism in Subcarpathia in more depth and detail, but the position that Subcarpathia is sociolinguistically heterogeneous is strongly supported.

\section{Works Cited}

Auer, Peter and Frans Hiskens. 1996. "The Convergence and Divergence of Dialects in Europe: New and not so New Developments in an Old Area." In Ammon, Ulrich, Klaus J. Mattheier, and Peter H. Nelde, eds. Sociolinguistica, International Yearbook of European Sociolinguistics, Volume 10: Convergence and Divergence of Dialects in Europe. Tübingen: Max Niemeyer; 1-30.

Balogh, Lajos. 1991. "A suksükölés" [The indicative use of the imperative/subjunctive of $t$-final verbs]. Kárpáti Igaz Szó, November 12, 1991, p. 3.

Bárdi, Nándor, Fedinec, Csilla, and Szarka, László, eds. 2011. Minority Hungarian Communities in the Twentieth Century. New York: Columbia University Press.

Bartha, Csilla. 1993. Egy amerikai magyar közösség nyelvhasználatának szociolingvisztikai megközelítései [Sociolinguistic approaches to the language use of a Hungarian American community]. Budapest: Kandidátusi dissertation.

Benő, Attila and Sándor Szilágyi N. 2005. "Hungarian in Romania”. In Fenyvesi, Anna, ed. 2005. Hungarian Language Contact Outside Hungary: Studies on Hungarian as a minority Language. Amsterdam/Philadelphia: John Benjamins Publishing Company. $133-163$. 
Csernicskó, István and Fenyvesi, Anna. "Sociolinguistic and Contact-induced Variation in Hungarian Language Use in Subcarpathia, Ukraine." AHEA: E-journal of the American Hungarian Educators Association, Volume 5 (2012): http://ahea.net/e-journal/volume-5-2012

Beregszászi, Anikó and Csernicskó, István. 2009. “The Linguistic Aspects of Current Ukrainian Educational Policy.” In Tarnóczy, Mariann and Kövér, Alexandra eds., 20 Years: Report on the Activities of the Sasakawa Young Leaders Fellowship Fund in Hungary 19892009: A Selection of 20 Studies from the Past 20 Years. Budapest: HAS-Sasakawa Young Leaders Fellowship Fund; 1-9.

Beregszászi, Anikó. 1995/1996. "Language Planning Issues of Hungarian Place-Names in Subcarpathia." Acta Linguistica Hungarica 43(3-4): 373-380.

Beregszászi, Anikó. 1997. "Kárpátaljai szavak a Magyar Értelmező Kéziszótárban?" [Subcarpathian words in the Concise Defining Dictionary of Hungarian?] Pánsíp 5(2): 24-27.

Botlik, József 2008. Eduard Beneš and Podkarpatská Rus: Hungarians, Rusins and Czechs in Subcarpathia 1919-1938/39. Budapest: Corvinus Publishing.

Botlik, József and György Dupka. 1993. Magyarlakta települések ezredéve Kárpátalján [A thousand years of the Hungarian populated settlements in Subcarpathia]. Užgorod and Budapest: Intermix Kiadó.

Chambers, J. K. 1995. Sociolinguistic Theory: Linguistic Variation and its Social Significance. Oxford: Blackwell.

Clyne, Michael and Sandra Kipp, eds. 1992. Pluricentric Languages in an Immigrant Context: Spanish, Arabic, and Chinese. Berlin: Mouton de Gruyter.

Clyne, Michael, ed. 1992. Pluricentric Languages. Berlin: Mouton de Gruyter.

Csernicskó, István and Fenyvesi, Anna. 2000. "The Sociolinguistic Stratification of Hungarian in Subcarpathia." Multilingua 19 (1-2): 95-122.

Csernicskó, István and Ferenc, Viktória. 2010. "Education as an Ideal Means of Achieveing a Nation State in Ukraine." In Róka, Jolán ed. Concepts and Consequences of Multilingualism in Europe. Budapest: Budapest College of Communication and Business; 329-349.

Csernicskó, István and Orosz, Ildikó. 1999. The Hungarians in Transcarpathia. Budapest: Tinta Publishers.

Csernicskó, István. 1997a. "A kárpátaljai magyarok kétnyelvüsége" [The bilingualism of the Hungarians in Subcarpathia]. Szivárvány 18(2): 117-124.

Csernicskó, István. 1997b. “A számok tükrében: Kárpátalja lakosságának nemzetiségi megoszlása a legutóbbi szovjet népszámlálás (1989) adatai alapján, némi kitekintéssel” [As mirrored in the numbers: Some comments on the nationality figures of the population of Subcarpathia as reported in the latest Soviet census of 1989]. Forrás 1997(2): 70-76.

Csernicskó, István. 1997c. "Kárpátaljai szójegyzék" [A list of Subcarpathian vocabulary]. Pánsíp $5(2): 28-29$.

Csernicskó, István. 2005. "Hungarian in Ukraine”. In Fenyvesi, Anna, ed. 2005. Hungarian Language Contact Outside Hungary: Studies on Hungarian as a Minority Language. Amsterdam/Philadelphia: John Benjamins Publishing Company. 89-133.

Daftary, Farimah and Gál, Kinga. 2000. The New Slovak Language Law: Internal or External Politics? ECMI Working Papers \# 8. http://www.ecmi.de/publications/

Deme, László. 1970. Nyelvi és nyelvhasználati gondjainkról [On our problems with language and language use]. Bratislava: Madách. 
Csernicskó, István and Fenyvesi, Anna. "Sociolinguistic and Contact-induced Variation in Hungarian Language Use in Subcarpathia, Ukraine." AHEA: E-journal of the American Hungarian Educators Association, Volume 5 (2012): http://ahea.net/e-journal/volume-5-2012

Dickinson, J. 2010. "Languages for the Market, the Nation, or the Margins: Overlapping Ideologies of Language and Identity in Zakarpattia." International Journal of the Sociology of Language 201: 53-78.

Eöry, Vilma. 2007. Értelmezö szótár+ [Defining dictionary plus]. Budapest: Tinta Kiadó. Fenyvesi, Anna, ed. 2005. Hungarian Language Contact Outside Hungary: Studies on Hungarian as a Minority Language. Amsterdam/Philadelphia: John Benjamins Publishing Company.

Fenyvesi, Anna. 1995. "Hungarian Diglossia in Slovakia: A New Linguistic Approach." Budapest Review of Booka 1995(2): 37-39.

Kenesei, István, Robert M. Vago, and Anna Fenyvesi. 1998. Hungarian. (Descriptive Grammars Series). London and New York: Routledge.

Fishman, Joshua A. 1968. "Sociolinguistic Perspective on the Study of Bilingualism." Linguistics 39, 21-49.

Goebl, Hans, Peter H. Nelde, Zdeněk Starý and Wolfgang Wölck (eds.) 1997. Contact Linguistics: An International Handbook of Ccontemporary Research, Volume 2. Berlin and New York: Walter de Gruyter.

Göncz, Lajos, and Ottó Vörös. 2005. "Hungarian in the Former Yugoslavia (Vojvodina and Prekmurje)". In Fenyvesi, Anna, ed. 2005. Hungarian Language Contact Outside Hungary: Studies on Hungarian as a Minority Language. Amsterdam/Philadelphia: John Benjamins Publishing Company. 187-241.

Grétsy, László and Miklós Kovalovszky (eds.) 1983. Nyelvmüvelö kézikönyv, I [Language cultivation handbook, Volume 1]. Budapest: Akadémiai Kiadó.

Györke, Magdolna. 1991. "A kárpátaljai magyar szaknyelvek" [Subcarpathian Hungarian registers]. In Győri-Nagy, Sándor and Janka Kelemen (eds.) Kétnyelvüség a Kárpátmedencében I [Bilingualism in the Carpathian Basin, Volume I]. Budapest: Széchenyi Társaság and Pszicholingva Nyelviskola; 70-71.

Horváth, Katalin. 1976. A kárpátontúli magyar nyelvjárások magánhangzórendszere [The vowel systems of the Hungarian regional dialects beyond the Carpathian Mountains]. Užgorod: Ungvári Állami Egyetem.

Horváth, Katalin. 1991. “Szebben beszélünk, mint Magyarországon?” [Do we speak a more beautiful Hungarian than people in Hungary?] Kárpáti Igaz Szó, November 13, 1991, p. 8.

Horváth, Katalin. 1998. “Újabb keletủ szláv átvételeink” [Our recent Eastern Slavic loanwords]. Kárpáti Igaz Szó, February 14, 1998, p. 13.

Iltio, I. ed. 2003. Наиіональний склад населення та його мовні ознаки (статистичний бюлетень). Ужгород: Закарпатське обласне управління статистики.

Kocsis, Károly and Kocsis-Hodosi, Eszter 1998. Ethnic Geography of the Hungarian Minorities in the Carpathian Basin. Budapest: Geographical research Institute and Minority Studies Programme.

Kontra, Miklós. 1995a. "Sociopolitical and Linguistic Aspects of Post-Communist Hungarian Contact Linguistics." In Muikku-Werner, P. and K. Julkunen (eds.) Kielten väliset kontaktit. AFinLAn vuosikirja 1995. Suomen soveltavan kieltieteen yhdisteyken (AFinLA) julkaisuja no. 53. Jyväskylä: AFinLa; 7-23. 
Csernicskó, István and Fenyvesi, Anna. "Sociolinguistic and Contact-induced Variation in Hungarian Language Use in Subcarpathia, Ukraine." AHEA: E-journal of the American Hungarian Educators Association, Volume 5 (2012): http://ahea.net/e-journal/volume-5-2012

Kontra, Miklós. 1995b. "Does the Educational Level of Speakers Matter in Hungarian Language Use?" In Viereck, Wolfgang (ed.) Proceedings of the International Congress of Dialectologists. Bamberg, 29.7. - 4.8. 1990. Vol. 4 Zeitschrift für Dialektologie und Linguistik, Beiheft 77. Stuttgart; 61-69.

Kontra, Miklós. 1997. "Hungarian Linguistic Traitors Champion the Cause of Contact Dialects." In Wölck, Wolfgang and A. de Houwer (eds.) Recent Studies in Contact Linguistics. Bonn: Dümmler; 181-187.

Kontra, Miklós. 1998. Final Report to the Research Support Scheme on 'The Sociolinguistics of Hungarian outside Hungary'. Budapest: Linguistics Institute, Hungarian Academy of Sciences MS.

Kontra, Miklós. 2001. "Hungarian Verbal Puzzles and the Intensity of Language Contact." Journal of Sociolinguistics 5: 163-179.

Kontra, Miklós. 2003. "Changing Mental Maps and Morphology: Divergence Caused by International Border Changes. " In David Britain and Jenny Cheshire (eds). Social Dialectology: In Honour of Peter Trudgill. Amsterdam/Philadelphia: John Benjamins; 173-190.

Kontra, Miklós. 2005. "Contextualizing the Sociolinguistics of Hungarian Outside Hungary project". In Fenyvesi, Anna, ed. 2005. Hungarian Language Contact Outside Hungary: Studies on Hungarian as a Minority Language. Amsterdam/Philadelphia: John Benjamins Publishing Company. 29-46.

Kótyuk, István. 1995. Anyanyelvünk peremén [On the outskirts of our mother tongue]. Užgorod and Budapest: Intermix Kiadó.

Langman, Juliet and Lanstyák, István. 2000. "Language Negotiations in Slovakia: Views from the Hungarian Minority." Multilingua 19(1-2): 55-72.

Langman, Juliet. 2002. "Mother-Tongue Education versus Bilingual Education: Shifting Ideologies and Policies in the Republic of Slovakia." International Journal of the Sociology of Language 154: 47-64.

Lanstyák, István and Gizela Szabómihályová. 2009. "Hungarian in Slovakia: Language Management in a Bilingual Minority Community." In: Nekvapil, Jiri and Tamah Sherman (eds.). Language Management in Contact Situations: Perspectives from three Continents. Frankfurt am Main: Peter Lang; 49-73.

Lanstyák, István and Gizella Szabómihály. 1996. "Contact Varieties of Hungarian in Slovakia: A Contribution to their Description." International Journal of the Sociology of Language 120: $111-130$.

Lanstyák, István and Gizella Szabómihály. 1997. Magyar nyelvhasználat - iskola - kétnyelvüség [Hungarian language use, schools, and bilingualism]. Bratislava: Kalligram Könyvkiadó.

Lanstyák, István and Gizella Szabómihály. 2005. "Hungarian in Slovakia”. In Fenyvesi, Anna, ed. 2005. Hungarian Language Contact Outside Hungary: Studies on Hungarian as a Minority Language. Amsterdam/Philadelphia: John Benjamins Publishing Company. 4788.

Lanstyák, István. 1994. "Kétnyelvüség és nemzeti nyelv" [Bilingualism and national language]. Irodalmi Szemle 37(2): 63-75.

Lanstyák, István. 1995a. "A magyar nyelv központjai” [The centers of the Hungarian language]. Magyar Tudomány, 40(10): 1170-1185. 
Csernicskó, István and Fenyvesi, Anna. "Sociolinguistic and Contact-induced Variation in Hungarian Language Use in Subcarpathia, Ukraine." AHEA: E-journal of the American Hungarian Educators Association, Volume 5 (2012): http://ahea.net/e-journal/volume-5-2012

Lanstyák, István. 1995b. “Többközpontú nyelv-e a magyar?” [Is Hungarian a pluricentric language?]. Irodalmi Szemle 38(1): 72-84.

Lizanec, P. N. 1992. A kárpátaljai magyar nyelvjárások atlasza, I. kötet [Atlas of Hungarian dialects in Subcarpathia, Volume 1]. Budapest: Akadémiai Kiadó.

Lizanec, P. N. 1996. A kárpátaljai magyar nyelvjárások atlasza, II. kötet [Atlas of Hungarian dialects in Subcarpathia, Volume 2]. Užgorod: Patent Nyomdaipari Vállalat.

Lizanyec P. N. and Katalin I. Horváth. 1981. "A kárpátontúli magyar nyelvjárások főbb sajátosságairól" [On the most important characteristics of regional dialects of Hungarian beyond the Carpathian Mountains]. Magyar Nyelvjárások 34: 3-18.

Magocsi, Paul Robert. 1996. "The Hungarians in Transcarpathia (Subcarpathian Rus')." Nationalities Papers 24(3): 525-534.

Milroy, Lesley. 1980. Language and Social Networks. Oxford: Blackwell.

Papp, Ferenc. 1969. Reverse-Alphabetized Dictionary of the Hungarian Language. Budapest: Akadémiai Kiadó.

Péntek, János. 2009. "Termini: The Network of Hungarian linguistic Research Centres in the Carpathian Basin." Minorities Research 11:97-123.

Poplack, Shana. 1993. "Variation Theory and Language Contact: Concepts, Methods and Data." In Preston, Dennis R. (ed.) American Dialect Research. Amsterdam: John Benjamins; 251-286.

Pusztai, Ferenc, gen. ed. 2003. Magyar értelmezö kéziszótár [Concise defining dictionary of Hungarian]. 2nd, revised edition. Budapest: Akadémiai Kiadó.

Rot, Sándor. 1967. "Magyar-ukrán és ukrán-magyar kétnyelvüség Kárpát-Ukrajnában" [Hungarian-Ukrainian and Ukrainian-Hungarian bilingualism in Subcarpathian Ukraine]. Magyar Nyelvör 91: 185-191.

Sándor, Klára. 1995. "Az élőnyelvi vizsgálatok és az iskola: A kisebbségi kétnyelvűség" [Sociolinguistic research and school: Minority bilingualism]. Regio 4(4): 121-148.

Sándor, Klára. 2000. "National Feeling or Responsibility: The Case of the Csángó Language Revitalization." Multilingua 19 (1-2): 141-168.

Shamshur, Oleg V. and Tetiana I. Izhevskaya. 1993. "Multilingual Education as a Factor of Inter-Ethnic Relations: The Case of the Ukraine." In Ager, D., G. Muskens, and S. Wright, eds. Language Education for Intercultural Communication. Clevedon, Philadelphia and Adelaide: Multilingual Matters: 159-167.

Szabómihály, Gizella. 1993. "Nyelvhasználat és szociális háttér" [Language use and social background]. Hungarológia 3: 59-72.

Váradi, Tamás and Miklós Kontra. 1995. "Degrees of Stigmatization: $t$-final Verbs in Hungarian." In Viereck, Wolfgang (ed.) Proceedings of the International Congress of Dialectologists. Bamberg, 29.7. - 4.8. 1990. Vol. 4 Zeitschrift für Dialektologie und Linguistik, Beiheft 77. Stuttgart; 132-142.

Vargha, András. 1996. MEDIT felhasználói füzet [MEDIT user's manual]. Budapest: Published by the author.

Vančo, Ildikó, ed. 2011. Language Policy, Dialect and Bilingualism: A Focus on Hungarian Language Use in Slovakia. Nitra: Arany László Polgári Társulás.

Vargha, András. 1997. MiniStat 2.4 verzió. Felhasználói füzet [MINISTAT, version 2.4: User's manual]. Budapest: Published by the author. 
Csernicskó, István and Fenyvesi, Anna. "Sociolinguistic and Contact-induced Variation in Hungarian Language Use in Subcarpathia, Ukraine." AHEA: E-journal of the American Hungarian Educators Association, Volume 5 (2012): http://ahea.net/e-journal/volume-5-2012

Vasvári, Louise O. 2011. "Grammatical Gender Trouble and Hungarian Gender[lessness]. Part 1: Comparative linguistic Gender". AHEA Journal 4. http://ahea.net/e-journal/volume-42011/17

Zel'ová, Alena. 1992. "The Integration of the Hungarian Minority in Slovakia: The Language Problem.” In Jana Plichtová (ed.). Minorities in Politics: Cultural and Language Rights. Bratislava: Czechoslovak Committee of the ECF; 155-158 